\title{
Myocardial transfection of hypoxia-inducible factor-1a and co-transplantation of mesenchymal stem cells enhance cardiac repair in rats with experimental myocardial infarction
}

\author{
Bingqing Huang ${ }^{\dagger}$, Juying Qian ${ }^{\dagger}$, Jianying Ma, Zheyong Huang, Yunli Shen, Xueying Chen, Aijun Sun, \\ Junbo $\mathrm{Ge}^{*}$ and Haozhu Chen
}

\begin{abstract}
Introduction: Mesenchymal stem cells (MSCs) have potential for the treatment of myocardial infarction. However, several meta-analyses revealed that the outcome of stem cell transplantation is dissatisfactory. A series of studies demonstrated that the combination of cell and gene therapy was a promising strategy to enhance therapeutic efficiency. The aim of this research is to investigate whether and how the combination of overexpression of hypoxia-inducible factor-1a (HIF-1a) and co-transplantation of mesenchymal stem cells can enhance cardiac repair in myocardial infarction.

Methods: We investigated the therapeutic effects of myocardial transfection of HIF-1a and co-transplantation of MSCs on cardiac repair in myocardial infarction by using myocardial transfection of HIF-1a via an adenoviral vector. Myocardial infarction was produced by coronary ligation in Sprague-Dawley (SD) rats. Animals were divided randomly into six groups: (1) HIF-1a + MSCs group: Ad-HIF-1a $\left(6 \times 10^{9}\right.$ plate forming unit) and MSCs $\left(1 \times 10^{6}\right)$ were intramyocardially injected into the border zone simultaneously; (2) HIF-1a group: Ad-HIF-1a $\left(6 \times 10^{9}\right.$ plate forming unit) was injected into the border zone; (3) HIF-1a-MSCs group: Ad-HIF-1a transfected MSCs $\left(1 \times 10^{6}\right)$ were injected into the border zone; (4) MSCs group: MSCs $\left(1 \times 10^{6}\right)$ were injected into the border zone; (5) Control group: same volume of DMEM was injected; (6) SHAM group. Cardiac performance was then quantified by echocardiography as well as molecular and pathologic analysis of heart samples in the peri-infarcted region and the infarcted region at serial time points. The survival and engraftment of transplanted MSCs were also assessed.
\end{abstract}

Results: Myocardial transfection of HIF-1a combined with MSC transplantation in the peri-infarcted region improved cardiac function four weeks after myocardial infarction. Significant increases in vascular endothelial growth factor (VEGF) and stromal cell-derived factor-1a (SDF-1a) expression, angiogenesis and MSC engraftment, as well as decreased cardiomyocyte apoptosis in peri-infarcted regions in the hearts of the HIF-1a+MSCs group were detected compared to the MSCs group and Control group.

Conclusions: These findings suggest that myocardial transfection of HIF-1a and co-transplantation of mesenchymal stem cells enhance cardiac repair in myocardial infarction, indicating the feasibility and preliminary safety of a combination of myocardial transfection of HIF-1a and MSC transplantation to treat myocardial infarction.

\footnotetext{
*Correspondence: jbge@zs-hospital.sh.cn

${ }^{\dagger}$ Equal contributors

Department of Cardiology, Shanghai Institute of Cardiovascular Diseases,

Zhongshan Hospital, Fudan University, 180 Feng Lin Road, Shanghai

200032, China
}

\section{Biomed Central}

(c) 2014 Huang et al.; licensee BioMed Central Ltd. This is an Open Access article distributed under the terms of the Creative Commons Attribution License (http://creativecommons.org/licenses/by/2.0), which permits unrestricted use, distribution, and reproduction in any medium, provided the original work is properly credited. The Creative Commons Public Domain Dedication waiver (http://creativecommons.org/publicdomain/zero/1.0/) applies to the data made available in this article unless otherwise stated. 


\section{Introduction}

Despite substantial therapeutic advances over the past decade, heart failure, due in large part to myocardial infarction (MI), remains a leading cause of morbidity and mortality worldwide. Stem cell transplantation, as a promising therapy for patients suffering from myocardial infarction, has recently been a research priority. It has huge potential for cardiac regeneration and cardiac function recovery. However, several meta-analyses revealed that the outcome of stem cell transplantation is dissatisfactory. Three to six months after the transplantation of bone marrow-derived stem cells, left ventricular ejection fraction (LVEF) was improved by merely 2.53 to $3.66 \%$, and major adverse cardiac events (MACE) were not significantly decreased [1-3]. The low homing rate and local survival rate of the transplanted cells, affected by endogenous and environmental factors in the ischemic tissue, such as hypoxia, oxidative stress and inflammation, which may result in apoptosis of transplanted cells [4-6], restrain the application of this technique. Strategies to improve cardiac homing and engraftment of stem cells may improve the outcome of this approach [7-12]. One interesting strategy is the combination of cell and gene therapy [13-16]. Satoshi Sintani et al. reported that combined intramyocardial CD $34^{+}$cells and VEFG2 gene therapy after MI results in better therapeutic effect than monotherapy, though the improvement of cardiac function is still not satisfactory [17].

Hypoxia-inducible factor- $1 \alpha$ (HIF- $1 \alpha)$ is a major regulator of the hypoxic response after myocardial infarction [16]. Decreased tissue oxygen causes nuclear accumulation of HIF- $1 \alpha$ protein and enhancement of its transcriptional activity through binding to enhancer elements in target genes, including vascular endothelial growth factor (VEGF) [18], angiopoietin-1 (Ang-1), angiopoietin-2 (Ang-2), platelet-derived growth factor beta [19], nitric oxide synthase (iNOS) [20], erythropoietin [21], phosphoglycerate kinase [22] and stromal-derived factor-1 (SDF-1). Specifically, the up-regulation of CXCR4 expression in mesenchymal stem cells (MSCs) mediates a broad range of biological processes including cell proliferation, survival, migration, adhesion, differentiation, as well as pro-angiogenesis [23-27].

Therefore, HIF- $1 \alpha$ regulates adaptation to hypoxia at the systemic, tissue and cellular levels $[28,29]$, including enabling transcriptional activation of angiogenesis genes, improving the recruitment of endothelial progenitor cells to areas of tissue ischemia through an SDF-1CXCR4 pathway [30], and affecting the activation of pro-inflammatory chemokine production by endothelium through transcriptional modulation of heme oxygenase-1 [31]. Therefore, HIF-1 $\alpha$ could be an ideal candidate to improve cell-mediated cardiac repair. Recently, Inmaculada Cerrada et al. [32] used HIF-1 $\alpha$-transfected MSC transplantation in a rat model of MI, and improvement was observed in terms of cardiac function, angiogenesis, cardiomyocyte proliferation and reduction of fibrotic tissue. It demonstrated that HIF-1 $\alpha$ gene therapy can enhance cell-mediated therapy for cardiac regeneration. However, the expression level of HIF-1 $\alpha$ in the ischemic area was not quantified in their study. Since the survival and engraftment of intramyocardial MSC transplantation were less than $5 \%$ at two weeks after transplantation [4-6], it is reasonable to deduce that the expression level of HIF- $1 \alpha$ from survived HIF- $1 \alpha$-transfected MSCs (HIF- $1 \alpha-$ MSC) in ischemic myocardium is very low, and enhanced HIF-1 $\alpha$ expression may lead to better results. Moreover, previous study demonstrated that exogeneous expression of HIF-1 $\alpha$ by using transfection is significantly higher compared to the endogenous HIF-1 $\alpha$ expression [29,33]. Thus, in order to get higher expression of HIF-1 $\alpha$ in the ischemic area instead of just the transplanted cells, we chose to use intramyocardial transfection of HIF-1 $\alpha$.

Accordingly, we plan to test the hypothesis that exogeneous expression of HIF-1 $\alpha$ in the ischemic area may increase the local survival and engraftment of the transplanted MSCs, enhance the angiogenesis, and improve cardiac performance in rats after myocardial infarction. Furthermore, we try to investigate whether intramyocardial transfection of HIF-1 $\alpha$ and co-transplantation of MSC transplantation has a better capacity of cardiac repair than the transplantation of $H I F-1 \alpha$-transfected MSCs.

\section{Materials and methods}

This study conformed to the guiding principles for the Care and Use of Laboratory Animals published by the US National Institutes of Health (NIH Publication No. 85-23, revised 1996). All animal protocols were approved by the Institutional Animal Care and Use Committee of Zhongshan Hospital, Fudan University, PR China. All surgeries were performed under ketamine anesthesia, and all efforts were made to minimize suffering.

\section{Isolation, culture and transfection of MSCs}

Isolation and culture of MSCs were performed as previously described [34]. In brief, MSCs were harvested from the femur and tibia of male Sprague-Dawley rats with a body weight of 80 to $100 \mathrm{~g}$, which were obtained from the Experimental Animal Center of Fudan University (Shanghai, China). Bone marrow cells were flushed and cultured with Iscove's Modified Dulbecco's Medium (Invitrogen/Gibco, Frederick, MD, USA) supplemented with $20 \%$ fetal bovine serum (FBS) and penicillin (100 $\mathrm{U} / \mathrm{ml}) /$ streptomycin $(100 \mu \mathrm{g} / \mathrm{ml})$ at $37^{\circ} \mathrm{C}$ in humid air with $5 \% \mathrm{CO}_{2}$. After being seeded for two days, MSCs adhered to the bottom of the culture plates, and the non-adherent cells were removed by a medium change at 48 hours. At $80 \%$ confluence, cells were harvested 
with $0.25 \%$ trypsin and passaged at a ratio of $1: 3$. The MSCs (P4) were identified with antibodies against CD105, CD166, CD45 and CD34 (fluorescein isothiocyanate conjugated, FITC).

MSCs were transfected with Ad-null-green fluorescent protein (Ad-null-GFP) or Ad-HIF-1 $\alpha$-GFP (Genechem Co. Ltd., Shanghai, China.) for $7 \mathrm{~h}$ followed by maintenance in the viral vector-free DMEM for $72 \mathrm{~h}$. The successful transduction was judged by the presence of green fluorescence. Randomly selected microscopic fields ( $\mathrm{n}>8$; $400 \times)$ at $72 \mathrm{~h}$ after transduction were evaluated to calculate the ratio of green cells to the total number of cells. These cells were further confirmed by immunostaining for HIF-1 $\alpha$ in either Ad-null-GFP transfected MSCs ( ${ }^{\text {Ad-Null }}$ MSCs) or $A d-H I F-1 \alpha-G F P$ transfected MSCs

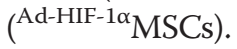

\section{Assessment of MSCs viability and proliferation}

A Cell Counting Kit-8 (CCK-8) (Sigma-aldrich, St. Louis, MO, USA) based colorimetric assay was used to quantify cell proliferation. The assay was performed at $12 \mathrm{~h}, 24 \mathrm{~h}$, $36 \mathrm{~h}$ and $48 \mathrm{~h}$ on MSCs, ${ }^{\text {Ad-Null }}$ MSCs and ${ }^{\mathrm{Ad}-\mathrm{HIF}-1 \alpha}$ MSCs. All MSCs were incubated with $10 \mu \mathrm{l}$ of CCK- 8 tetrazolium salt for $2 \mathrm{~h}$, and the absorbance was read using a microplate spectrofluorometer at a 450-nm wavelength. The number of living cells is directly proportional to the amount of formazan dye that can only be produced by viable cells and generated by the activity of dehydrogenase. The proliferation experiments were repeated three times with each condition tested in triplicate.

\section{MSCs migration assay}

To study the effect of HIF- $1 \alpha$ on MSC migration, 10,000 cells treated with or without $H I F-1 \alpha$ transfection were seeded in the top chamber of an $8 \mathrm{~mm}$-pore migration transwell (Corning, Inc. New York, NY, USA), supplemented with $600 \mu \mathrm{l}$ DMEM culture medium containing $0.5 \%$ FBS in the bottom chamber. After incubation for 12 hours, the inside of the transwells were wrapped with a cotton bud to remove non-migrating cells, the membrane was cut and placed on a glass slide with the bottom side upward, and 4, 6-diamino-2-phenylindole (DAPI) (Life Technologies Corporation, Carlsbad, CA, USA.) was added to stain the nuclei and the migrated cells were counted. The assay was performed in duplicated wells and repeated three times.

\section{Cell labeling}

MSCs were stained by using $10 \mu \mathrm{g} / \mathrm{mL} 1,1$-dioctadecyl3,3,3,3-tetramethyl indotricarbocyanine Iodide (DiR, ABD Bioquest, Inc., Sunnyvale, CA, USA) as previously described [35-37]. Cells were then resuspended in growth media at a density of $25 \times 10^{6}$ cells $/ \mathrm{mL}$ and then kept on ice before transplantation.

\section{Animal model of myocardial infarction}

The experimental animals used in this study were eightweek-old female SD rats. Rats were intraperitoneally anesthetized with ketamine (15 to $20 \mathrm{mg} / \mathrm{kg}$ ). A midline anterior cervical skin incision was made and the trachea was exposed by sharp dissection. The trachea was intubated with an angiocatheter and ventilated to a rodent ventilator with room air. A $1.5 \mathrm{~cm}$ vertical left parasternal skin incision was made, the chest cavity was entered through the fourth interspace, and the pericardium was vertically opened. The left anterior descending coronary artery (LAD) was ligated with a 6-0 polypropylene suture. Ventricle blanching indicated successful occlusion of the vessel. Sham-operated animals served as surgical controls and were subjected to the same procedures as the experimental animals with the exception that the LAD was not ligated. Mortality rates during and after surgery were less than $5 \%$ in all groups.

\section{Implantation of MSCs and Ad-HIF-1a transfection}

Female adult SD rats $(n=180)$ were randomly divided into six groups. Immediately after ligation of the LAD, the HIF$1 \alpha+$ MSCs group $(n=30)$ received $1 \times 10^{6}$ MSCs and $6 \times$ $10^{12}$ plate forming unit (PFU) Ad-HIF-1 $\alpha$ resuspended with 40 ul DMEM, respectively; the HIF- $1 \alpha$ group $(n=30)$ received $6 \times 10^{12}$ PFU Ad-HIF-1 $\alpha$ and 40 ul DMEM; the HIF-1 $\alpha$-MSCs group $(\mathrm{n}=30)$ received $1 \times 10^{6}$ Ad-HIF${ }^{1 \alpha}$ MSCs and $6 \times 10^{12}$ PFU Ad-null (Genechem Co. Ltd, Shanghai, China); the MSCs group $(\mathrm{n}=30)$ received $1 \times 10^{6}$ Ad-Null MSCs and $6 \times 10^{12} \mathrm{PFU}$ Ad-null; and the Control group $(\mathrm{n}=30)$ received $6 \times 10^{12} \mathrm{PFU}$ Ad-null and $40 \mathrm{ul}$ DMEM; the SHAM group $(n=30)$ was subjected to the same procedure as the experimental animals with the exception that the LAD was not ligated. Cells and adenovirus were directly injected into the ischemic border zone of the myocardium at four different sites ( $20 \mu \mathrm{l}$ to each site).

\section{Immunostaining}

For HIF-1 $\alpha$ staining, MSCs were fixed for 30 minutes with $4 \%$ paraformaldehyde and permeabilized for 10 minutes with $0.2 \%$ Triton X-100. Cells were blocked with PBS containing $10 \% \mathrm{FBS}$ overnight at $4^{\circ} \mathrm{C}$ and incubated with mouse monoclonal anti-HIF- $1 \alpha$ antibody (Abcam Biochemicals, Cambridge, UK) at a dilution of 1:100. After thoroughly washing, the cells were incubated with secondary antibodies of goat anti-mouse IgG conjugated with rhodamine (Sigma-aldrich, St. Louis, MO, USA) at a dilution of 1:500 for $1 \mathrm{~h}$ at room temperature. Nuclei were stained with DAPI.

Opti-mum cutting temperature compound (O.C.T compound) embedded hearts were sectioned into $5 \mu \mathrm{m}$ slices. Adjacent sections (taken at the midpoint between LAD ligation site and apex) were double stained with antibodies against rat CD31 (Abcam Biochemicals, 
Cambridge, UK) and $\alpha$-SA ( $\alpha$-sarcomeric actinin) (Abcam Biochemicals, Cambridge, UK). Capillary density was defined as $\mathrm{CD}^{+} 1^{+}$endothelial cells per high-power field $(200 \times)$. Five high-powered fields were counted per section, with 10 sections/heart, and 10 hearts/group. Angiogenesis in the infarction/peri-infarcted regions was confined to vessels measuring less than $200 \mu \mathrm{m}$ in diameter.

Apoptosis of cardiomyocytes in the border zone was detected by terminal deoxynucleotidyl transferase dUTP nick end labeling (TUNEL) staining (Roche, Mannheim, Germany) at seven days after the surgical procedure. The number of TUNEL-positive nuclei and the total number of nuclei in three different fields ( $\times 400$ magnification) were counted by a blinded rater in the border zone $(n=5$ in each group). Cardiomyocyte apoptosis is expressed as the ratio of TUNEL-positive nuclei to the total number of cardiomyocyte nuclei.

\section{Echocardiography}

Transthoracic echocardiography (VEVO 770 Sonic, Seattle, WA, USA) was performed at one week, two weeks and four weeks post-infarction in each group. LVEF and fractional shortening (FS) were measured as previously described [38]. All measurements were averaged for three consecutive cardiac cycles.

\section{RT-PCR}

The total RNA was isolated from the peri-infarcted myocardial tissues at one week, two weeks and four weeks after surgery ( $\mathrm{n}=4$ in each group at each time point) using TRIzol reagent (Life Technologies Corporation, Carlsbad, CA, USA). The mRNA levels of HIF-1 $\alpha, S D F-1 \alpha, V E G F$ were determined by using RT-PCR. The primer sequences of

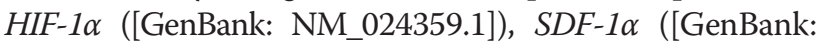
NM_001033882.1]), VEGF ([GenBank: NM_00111033 3.1]) and $\beta$-actin ([GenBank: NM_031144.3]) were shown

Table 1 Sequence of the primers used in the study

\begin{tabular}{lll}
\hline $\begin{array}{l}\text { Gene } \\
\text { symbol }\end{array}$ & Primer sequence & $\begin{array}{l}\text { Product size } \\
\text { (base pair) }\end{array}$ \\
\hline HIF-1a & Sense: 5'- ATGTGACCATGAGGAAATGAGAGAA-3' & 186 \\
& Antisense: 5'- ACGTGAATGTGGCCTGTGCA -3' & \\
VEGF & Sense: 5'-TGCACCCACGACAGAAGGGGA-3' & 364 \\
& Antisense: 5'-TCACCGCCTGGCTTGTCACAT-3' & \\
SDF-1a & Sense: 5'-AGATGCCCCTGCCGATTCTTG-3' & 118 \\
& Antisense: 5'-TGTGTTGCTTTCAGCCTTGC-3' & \\
B-actin & Sense: 5'-TCAGGTCATCACTATCGGCAAT-3' & 432 \\
& Antisense: 5'-AAAGAAAGGGTGTAAAACGCA-3' & \\
SRY & Sense: 5'-TCTGCTCCTACCTATGCCAACA-3' & 22 \\
& Antisense: 5'-GAGGGAACTCAGTATCCAAACCA-3' & \\
\hline
\end{tabular}

in Table 1. PCR conditions were: 40 cycles of denaturation at $95^{\circ} \mathrm{C}$ for 30 seconds, annealing at $60^{\circ} \mathrm{C}$ for 30 seconds and extension at $72^{\circ} \mathrm{C}$ for 30 seconds. The PCR products were subject to electrophoresis on $1.5 \%$ agarose gels, scanned and semi-quantitated by using Image-Quant software (Kodak 1D V3.53).

\section{Quantification of engraftment by real-time PCR}

MSCs isolated from male SD rats were injected into female rats, enabling detection of the SRY gene (located on the Y chromosome ([GenBank: FJ168067.1]) as an index of engraftment. Quantitative RT-PCR was performed at one week and three weeks after injection ( $n=5$ for each group). The whole heart was harvested, weighed and homogenized. Genomic DNA was extracted by using the Purelink genomic DNA kit (Life Technologies Corporation, Carlsbad, CA, USA) and quantified with the Quant-it DSDNA assay kit. Triplicate real-time PCR reactions were performed using $50 \mathrm{ng}$ of the genomic DNA. The real-time PCR conditions consisted of an initial denaturation step of 10 minutes at $95^{\circ} \mathrm{C}$, followed by 40 cycles at $95^{\circ} \mathrm{C}$, for $15 \mathrm{sec}$, and at $58^{\circ} \mathrm{C}$, for 1 minute. A standard curve was generated with multiple dilutions of genomic DNA isolated from male hearts to quantify the absolute gene copy numbers.

\section{Fluorescence imaging}

Fluorescence imaging was performed at three weeks after cell injection ( $\mathrm{n}=5$ for each group). Extensive PBS washing was performed to remove cells adherent to the epicardium. Hearts were placed in a Carestream In-Vivo Multispectral Imaging System FX PRO (Carestream Health, Inc., Rochester, NY, USA) to detect DiR fluorescence under $748 \mathrm{~nm}$ of excitation and $780 \mathrm{~nm}$ of emission. The exposure time was set at $3 \mathrm{sec}$ and was maintained during the entire imaging session. Hearts from the Control group were also imaged to normalize the noise from background. The fluorescent intensity was calculated using Kodak MI software 5.0.1. Fluorescence signals (photon $/ \mathrm{s} / \mathrm{mm}^{2}$ ) from a fixed region of interest (ROI) were measured as previously described [39].

\section{Statistics}

Continuous variables with normal distribution were expressed as average \pm standard deviation and compared by using Holm's $t$-test or variance analysis (ANOVA). Categorical variables were expressed as frequencies and percentages. For comparisons between different groups, the chi-square test or Fisher's exact test was used. A bi-caudal value of $P<0.05$ was considered as statistically significant. 


\section{Results \\ Transfection efficiency of Ad-null-GFP and Ad-HIF-1a-GFP in MSCs}

Immunostaining showed that the isolated MSCs (P4) (Figure 1A I) uniformly expressed CD105 and CD166 (see Additional file 1A), but not CD45 or CD34. The differentiation assay confirmed the differentiation potentials of the isolated MSCs into osteoblasts, adipocytes and chondrocytes (see Additional file 1B). The MSCs with a fusiform shape were distributed uniformly at $24 \mathrm{~h}$ after transfection with $A d$-null-GFP. (Figure 1A II) or Ad-HIF$1 \alpha-G F P$ (Figure 1A III), and the majority of the cells ( $94 \pm$ $3.5 \%$ and $93 \pm 3.8 \%$, respectively) expressed GFP. Immunofluorescence confirmed the expression of $H I F-1 \alpha$ in GFP + cell. It was also found that HIF-1 $\alpha$ was not only distributed in the cytoplasm of MSCs but also concentrated in the peri-nucleus (Figure 1B).

\section{Effects of Ad-null-GFP and Ad-HIF-1a-GFP on MSCs}

After transfection, cell viability and proliferation of each group were determined (Figure 1A IV). Viability and proliferation rates of ${ }^{\mathrm{Ad}-\mathrm{HIF}-1 \alpha} \mathrm{MSCs}$ group were higher than other groups during the first two days after transfection $(P<0.01)$, indicating that HIF-1 $\alpha$ may improve the cell viability and proliferation in vitro. Meanwhile, viability and proliferation rates of the ${ }^{\text {Ad-null }}$ MSCs group $24 \mathrm{~h}$ after transfection decreased compared to the MSCs group $(P<0.01)$, indicating that the transfection process might mildly affect the viability and proliferation of MSCs.

The representative photographs of MSC migration stained with DAPI were shown in Figure $1 \mathrm{C}$. The migration was significantly increased in the ${ }^{\text {Ad-HIF- } 1 \alpha}$ MSCs compared to other groups $(P<0.01)$. These results demonstrated that HIF-1 $\alpha$ can improve the cell viability, proliferation and motility of MSCs.

Gene expression in the peri-infarcted regions of the heart After the transplantation of MSCs and transfection of $H I F-1 \alpha$, we first evaluated the mRNA expression of $H I F-1 \alpha$ in the peri-infarcted region of the heart via RT-PCR. $H I F-1 \alpha$ mRNA expressions were significantly higher at one week, two weeks and four weeks post transfection in the HIF-1 $\alpha+$ MSCs group and the HIF- $1 \alpha$ group than other groups, indicating the successful transfection of the $H I F-1 \alpha$ gene (Figure 2A1-A3). Specifically, at one week, two weeks and four weeks after operation, levels of HIF-1 $\alpha$ mRNA in the HIF-1 $\alpha+$ MSCs group increased for 6.4, 2.3 and 2.7 times over levels in the Control group, respectively. The HIF-1 $\alpha-$ MSCs group showed slight increase in HIF-1 $\alpha$ mRNA expression compared to the Control group at one week and two weeks after operation (Figure 2A1, A2). Although the Control group manifested significant increase in $H I F-1 \alpha$ mRNA expression compared to the SHAM group at one week after operation (Figure 2A1), levels of HIF-1 $\alpha$ mRNA were as low as the SHAM group (Figure 2A2, A3) at both two weeks and four weeks after infarction, indicating a temporary increase of HIF- $1 \alpha$ due to acute ischemia after surgery.

We then evaluated two downstream genes whose transcriptional activities are directly modulated by $H I F-1 \alpha$, $S D F-1 \alpha$ and VEGF. Similarly, both $S D F-1 \alpha$ and VEGF mRNA levels were significantly higher at one week, two weeks and four weeks post transfection in HIF-1 $\alpha+$ MSCs group and HIF-1 $\alpha$ group than other groups (Figure 2B1-B3, C1-C3). Specifically, at one week, two weeks and four weeks after infarction, levels of $S D F-1 \alpha$ mRNA in HIF-1 $\alpha+$ MSCs group increased for 2.6, 2.6 and 2.3 times over levels in Control group, respectively (Figure 2B1-B3), while levels of VEGF mRNA increased for 3.8, 3.7 and 3.8 times (Figure 2C1-C3), suggesting that overexpressed $H I F-1 \alpha$ increased the expression of $S D F-1 \alpha$ and VEGF. The mRNA level of VEGF in the HIF-1 $\alpha$ MSCs and MSCs group increased for 2.3 and 0.5 times, respectively, over levels detected in Control group at one week after infarction (Figure 2C1). Although the Control group manifested a two-fold and three-fold increase in $S D F-1 \alpha$ and VEGF mRNA expression compared to SHAM group at one week after operation (Figure 2B1, C1), by two weeks and four weeks after infarction, levels of $S D F-1 \alpha$ and $V E G F$ mRNA were as low as SHAM group, which is consistent with the expression pattern of $H I F-1 \alpha$ (Figure 2B3, C2-C3).

\section{The cell engraftment in the recipient hearts}

Frozen sections were detected under a fluorescence microscope. More engrafted MSCs, which were originally stained with DiR (red) before transplantation, were observed in HIF- $1 \alpha+$ MSCs group and HIF- $1 \alpha-$ MSCs group than that of MSCs group (Figure 3A). Likewise, fluorescence imaging revealed more red fluorescence in hearts from the HIF- $1 \alpha+$ MSCs group and the HIF- $1 \alpha-M S C s$ group (Figure $3 \mathrm{~B}$ ) compared to the MSCs group, indicating that exogeneous HIF-1 $\alpha$ expression may improve the survival rate of MSCs. Optical density showed approximately a 0.26 -fold and 0.33 -fold increase in the HIF- $1 \alpha+$ MSCs group and the HIF-1 $\alpha-$ MSCs group compared to the MSCs group (Figure 3C). However, no difference was found between the HIF- $1 \alpha+$ MSCs group and the HIF-1 $\alpha$-MSCs group.

To further quantitatively compare the survival rate of transplanted MSCs in the myocardium between different groups, quantitative PCR for the male-specific SRY gene was performed at one week and three weeks after cell injection. PCR results indicated that all of the three groups experienced a huge decrease of engrafted MSCs during the three weeks (Figure 3D). The survival rate of the transplanted MSCs declined from $7.4 \%$ to $1.5 \%$ in the HIF- $1 \alpha+$ MSCs group, from $7.8 \%$ to $1.4 \%$ in the HIF- $1 \alpha-$ 


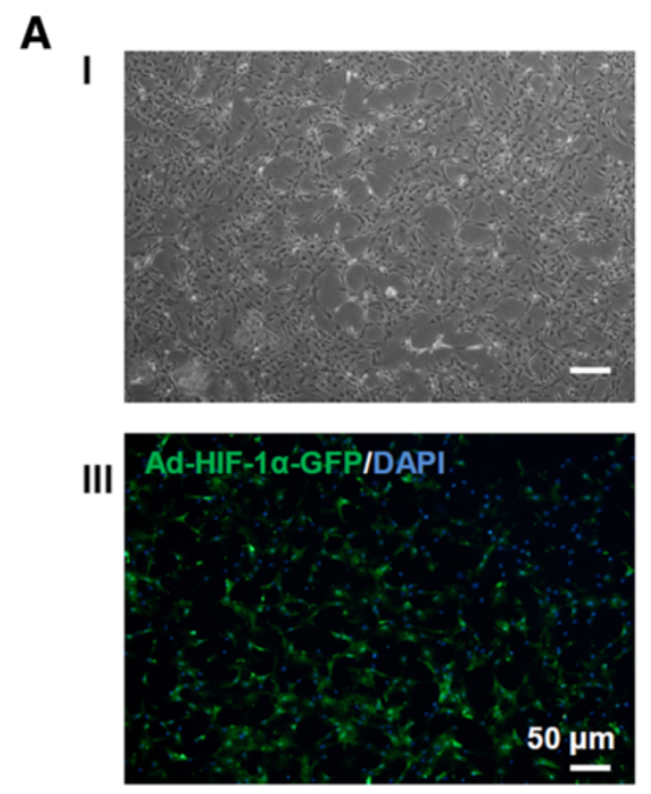

B
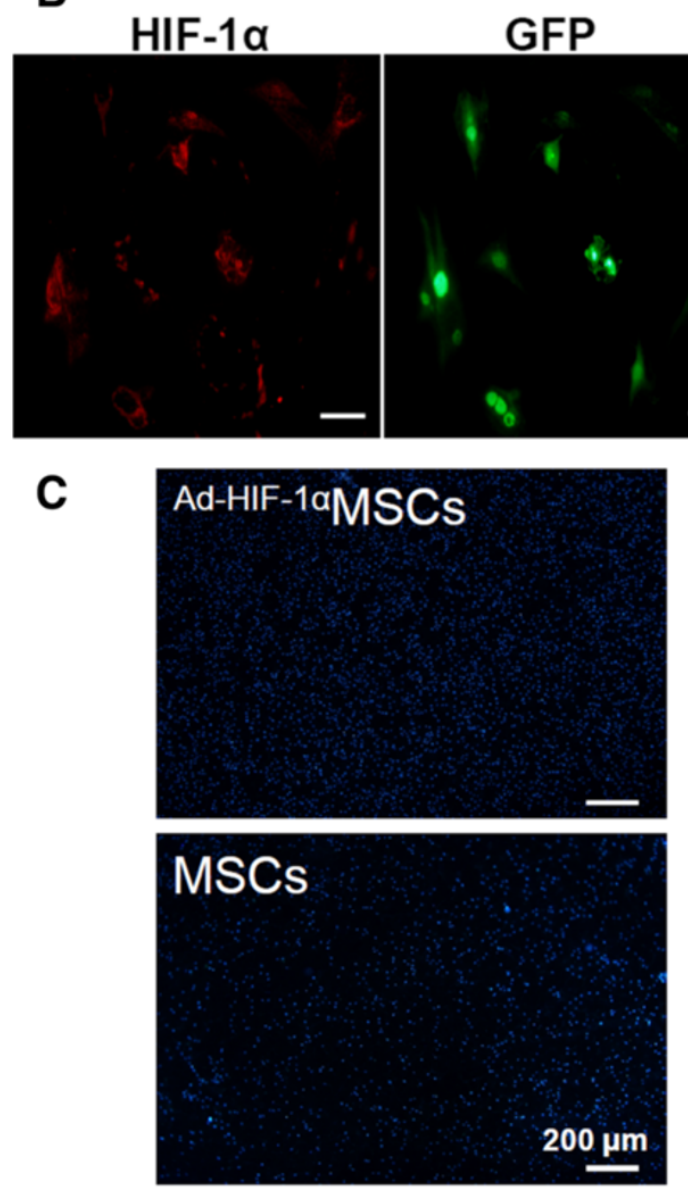
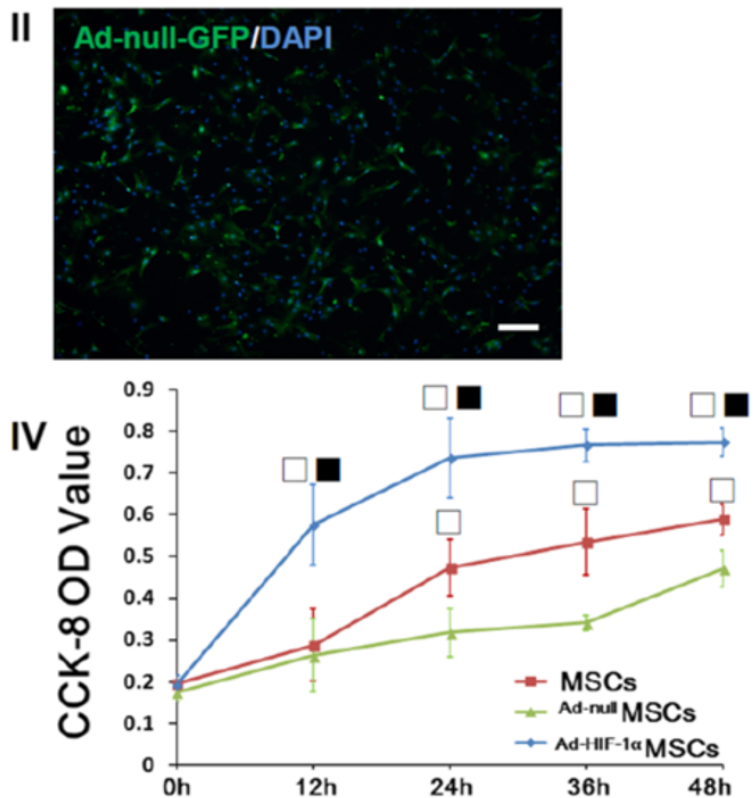


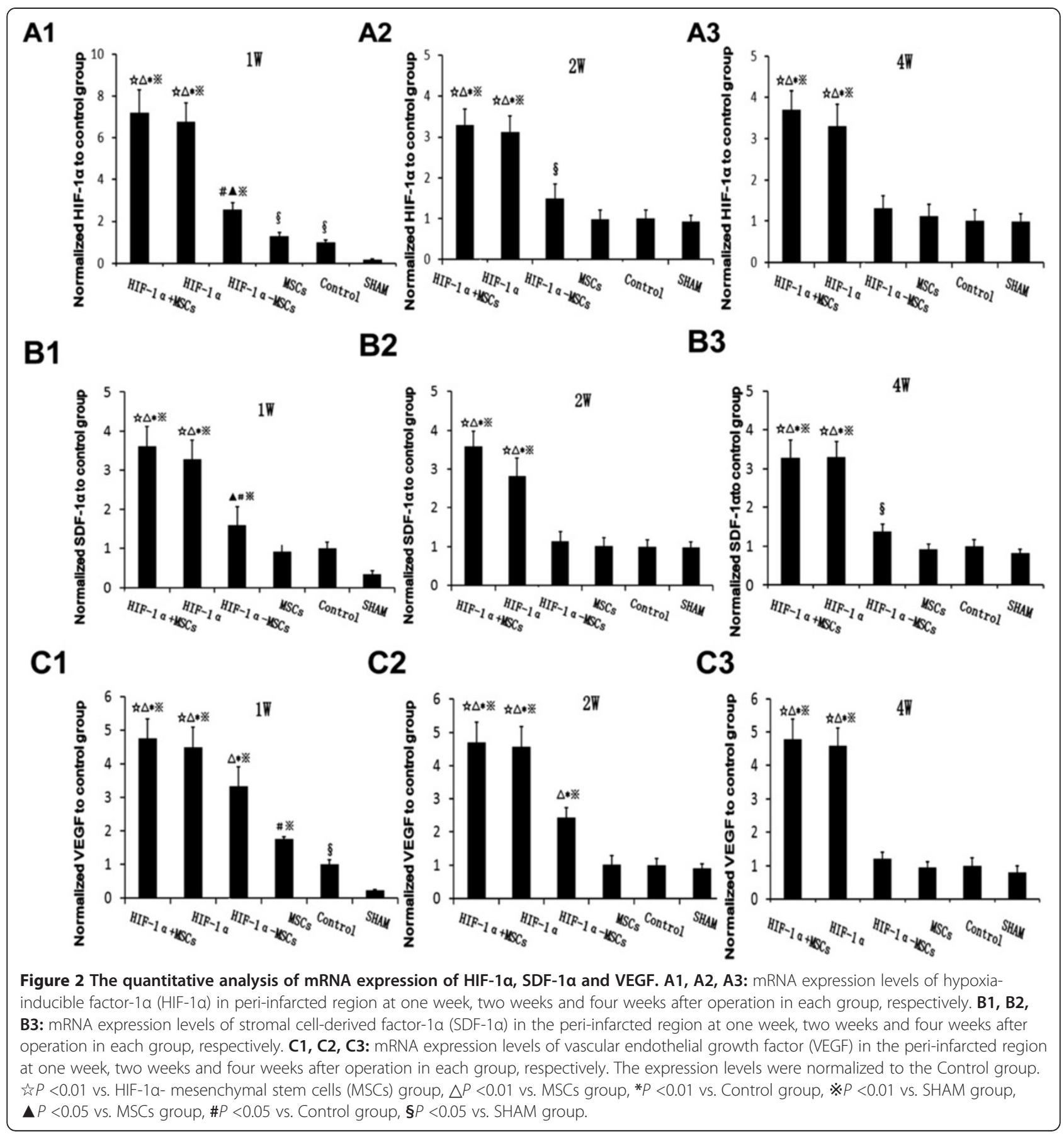

MSCs group, and from $6.6 \%$ to $0.7 \%$ in the MSCs group. However, the HIF- $1 \alpha+$ MSCs and HIF- $1 \alpha-$ MSCs groups still exhibited enhanced cell engraftment relative to the MSCs group at both one week (7.4\% vs. $7.8 \%$ vs. $6.6 \%, P=$ $0.001)$ and three weeks $(1.5 \%$ vs. $1.4 \%$ vs. $0.7 \%, P<0.05)$ after cell injection (Figure 3D).

The migration of MSCs into the infarction area At three weeks after cell transplantation, hearts from six animals in each group were harvested and cryosectioned for histological analysis. Under a fluorescence microscope, engrafted MSCs were detected not only in the peri-infarcted region where cells were originally injected, but also widely distributed in the infarction region. More engrafted MSCs were detected in the infarction region of hearts from the HIF- $1 \alpha+$ MSCs group compared to the HIF- $1 \alpha-M S C s$ and MSCs groups (Figure 4A), indicating the migration of transplanted MSCs to the ischemic region of the infarcted heart can be enhanced by exogeneous HIF- $1 \alpha$ expression. 


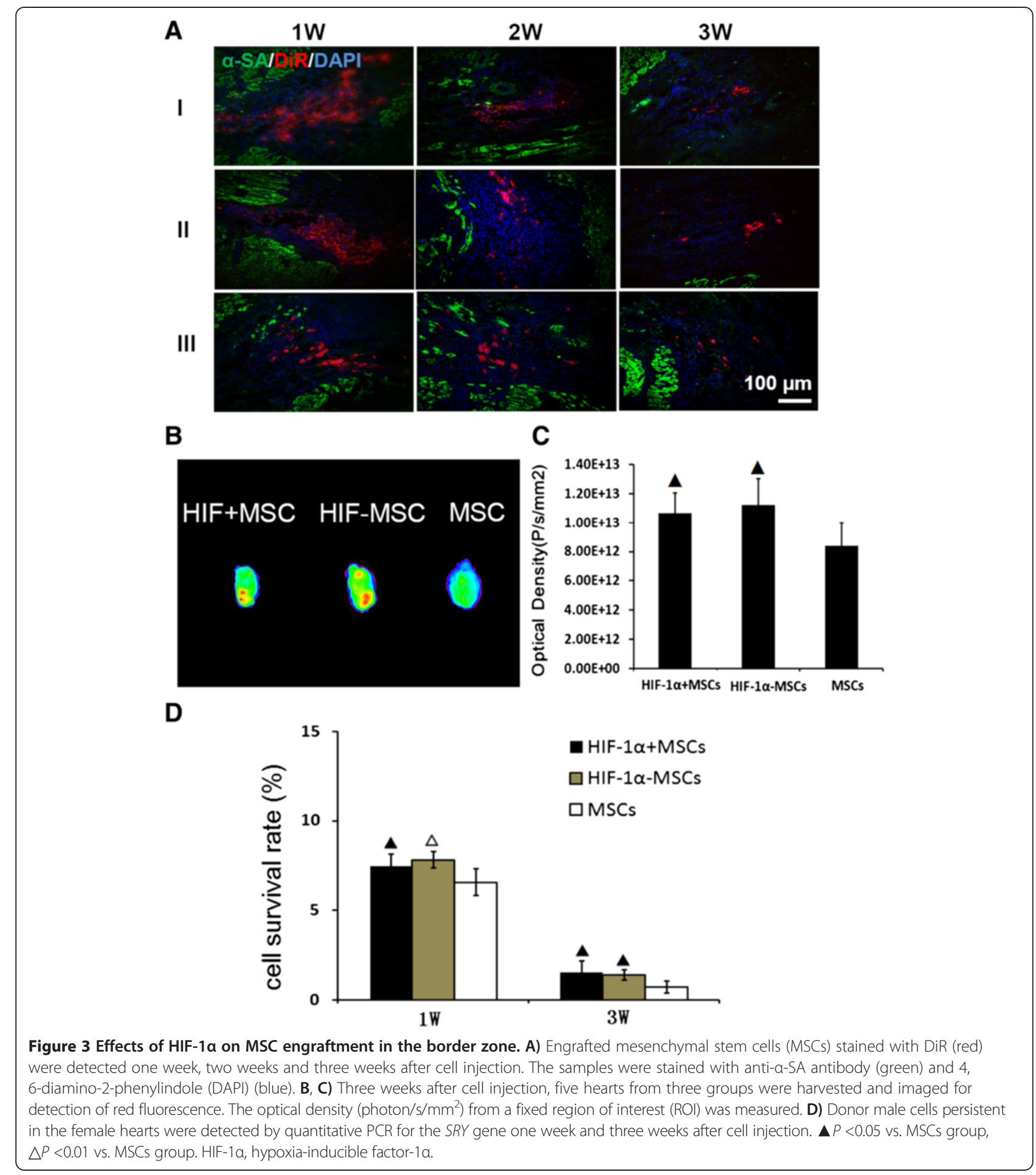

Sections were then stained for CD31 and counterstained with DAPI. Confocal microscopy was performed for detection of transplanted cells. It was detected that some engrafted MSCs were co-localized with the angiogenic marker CD31 (Figure 4B), suggesting that the transplanted cells may enhance angiogenisis.

\section{Vascular density measurement}

To assess the angiogenic effect of constitutive HIF- $1 \alpha$ expression and MSC transplantation, we measured vascular density in the peri-infarcted (border zone) region adjacent to the infarction (Figure 5) and within the infarction region of the left ventricle (Figure 6) at four weeks after 


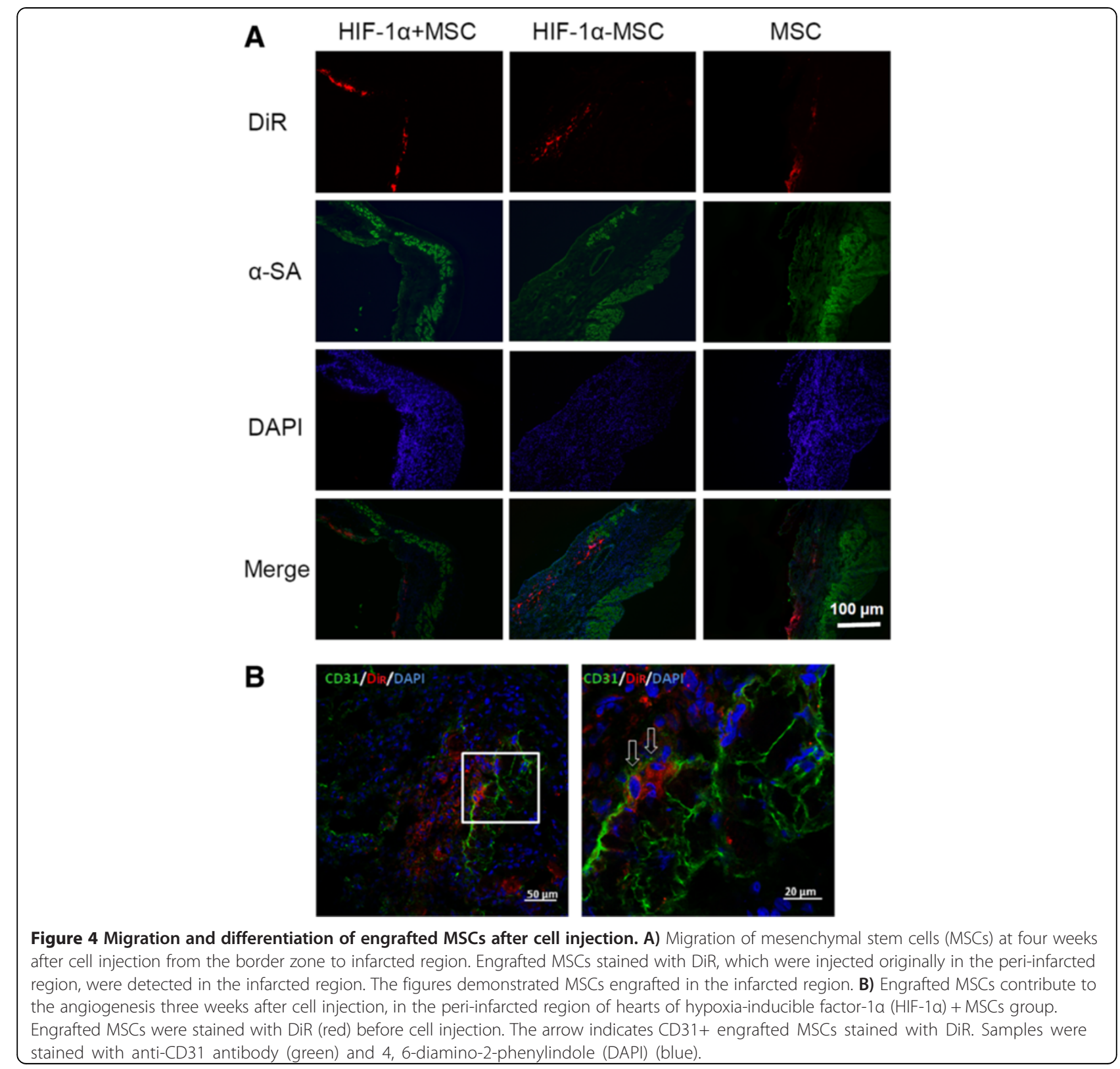

coronary ligation. We excised hearts and performed immunohistochemical staining with antibody against CD31 to detect endothelial cells. In the peri-infarcted area (Figure $5 \mathrm{~A}, \mathrm{~B})$, the capillary density observed in the hearts from HIF- $1 \alpha+$ MSCs group $\left(1,364 \pm 128 / \mathrm{mm}^{2}\right)$ was significantly higher than that of HIF- $1 \alpha$ group $\left(1,226 \pm 140 / \mathrm{mm}^{2}\right.$; $P<0.05)$, HIF- $1 \alpha$-MSCs group $\left(989 \pm 110 / \mathrm{mm}^{2}, P<0.01\right)$, MSCs group $\left(849 \pm 111 / \mathrm{mm}^{2} ; P<0.01\right)$, and Control group $\left(630 \pm 97 / \mathrm{mm}^{2} ; P<0.01\right)$. The capillary density of the HIF-1 $\alpha$ group was significantly higher than the HIF- $1 \alpha-$ MSCs, MSCs and Control groups $(P<0.01)$. The capillary density of the HIF-1 $\alpha$-MSCs group was higher compared to the MSCs $(P<0.05)$ and Control groups $(P<0.01)$. Within the site of infarction (Figure 6A, B), the capillary density of the HIF- $1 \alpha+$ MSCs group $\left(978 \pm 114 / \mathrm{mm}^{2}\right)$ was also significantly higher than that of the HIF- $1 \alpha \quad\left(812 \pm 91 / \mathrm{mm}^{2}\right.$; $P<0.01)$, the HIF- $1 \alpha-$ MSCs $\left(640 \pm 94 / \mathrm{mm}^{2} ; P<0.01\right)$, the MSCs $\left(573 \pm 82 / \mathrm{mm}^{2} ; P<0.01\right)$, and the Control groups $\left(469 \pm 53 / \mathrm{mm}^{2} ; P<0.01\right)$. The capillary density of the HIF- $1 \alpha$ group was significantly higher than the HIF-1 $\alpha$-MSCs, MSCs and Control groups $(P<0.01)$. The capillary density of the HIF- $1 \alpha-$ MSCs group was higher compared to the MSCs and Control groups $(P<0.01)$. Grossly and microscopically, no angioma formation was observed in any treated animals or controls. The increased capillary density was mainly 


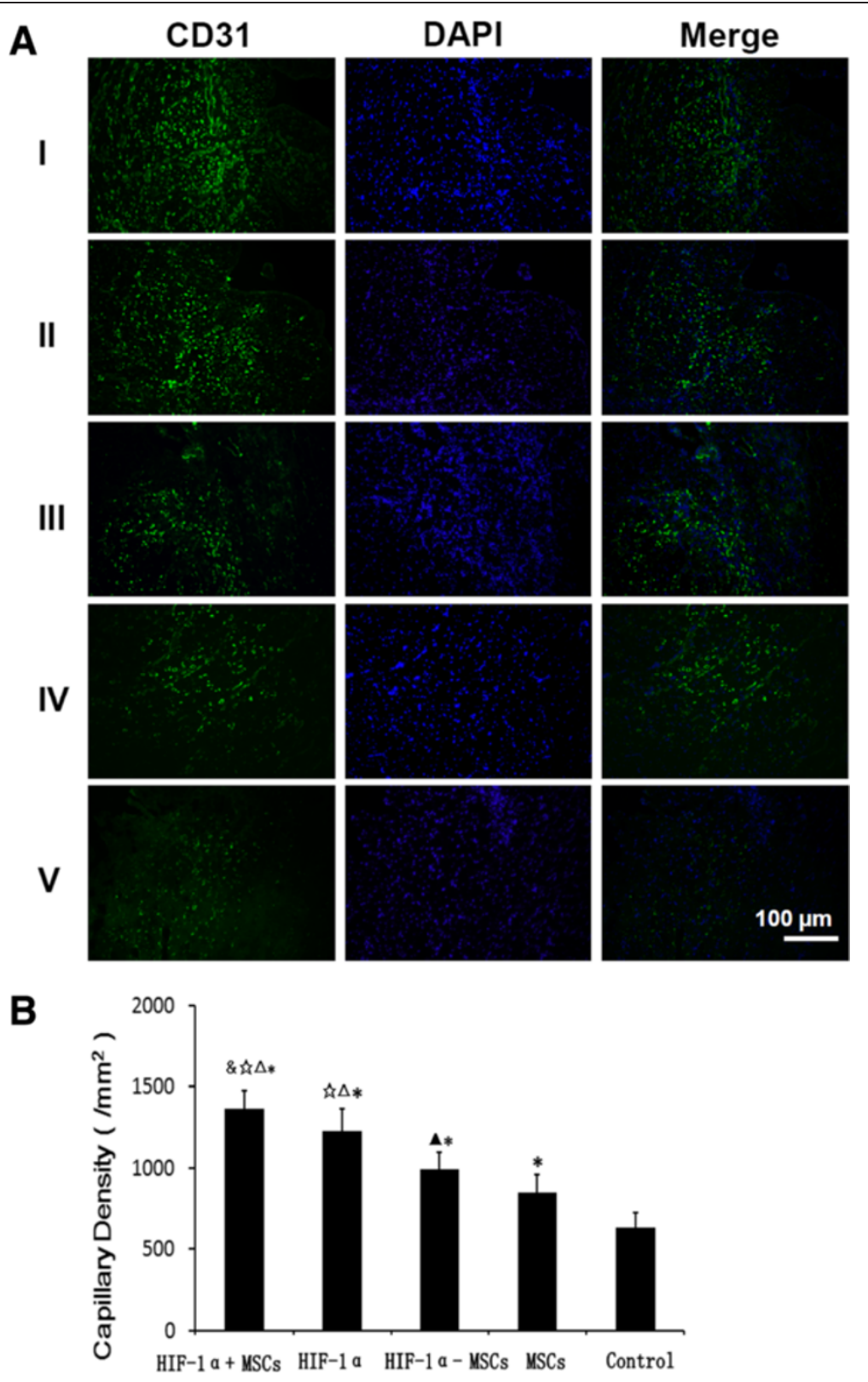

Figure 5 Capillary densities at the peri-infarcted border zone in each group. A) More capillary densities were detected in the hypoxiainducible factor-1a (HIF-1a) + mesenchymal stem cells (MSCs) group than other groups. (I) HIF-1a + MSCs group, (II) HIF-1a group, (III) HIF-1aMSCs group, (IV) MSCs group, (V) Control group. B) The number of CD-31-stained capillary was expressed as the number $/ \mathrm{mm}^{2}$. \&P $<0.05 \mathrm{vs}$. HIF-1a group, is $P<0.01$ vs. HIF-1a-MSCs group, $\triangle P<0.01$ vs. MSCs group, $* P<0.01$ vs. Control group, $\boldsymbol{\Delta} P<0.05$ vs. MSCs group.

limited to the area around the infarcted and periinfarcted area.

\section{Cell apoptosis in the infracted area}

Apoptotic extent was assessed via TUNEL staining. The number (as a percentage of the total) of cardiomyocytes showing apoptosis in the border zone was compared among groups (Figure $7, \mathrm{n}=5$ in each group). The percentage of apoptotic cells was reduced in the HIF- $1 \alpha+$ MSCs group $(18.08 \pm 4.59 \%)$ when compared to the HIF- $1 \alpha-$ MSCs $(24.43 \pm 5.68 \%, P<0.05)$, MSCs $(27.53 \pm 4.90 \%, P$ $<0.01)$ and Control groups $(35.51 \pm 4.03 \%, P<0.01)$. The HIF-1 $\alpha$ group $(20.36 \pm 4.88 \%)$ showed decreased cell apoptosis compared to the MSCs $(P<0.01)$ and Control groups $(P<0.01)$. The HIF-1 $\alpha$-MSCs group showed less cell apoptosis when compared to the Control group $(P<0.01)$. 


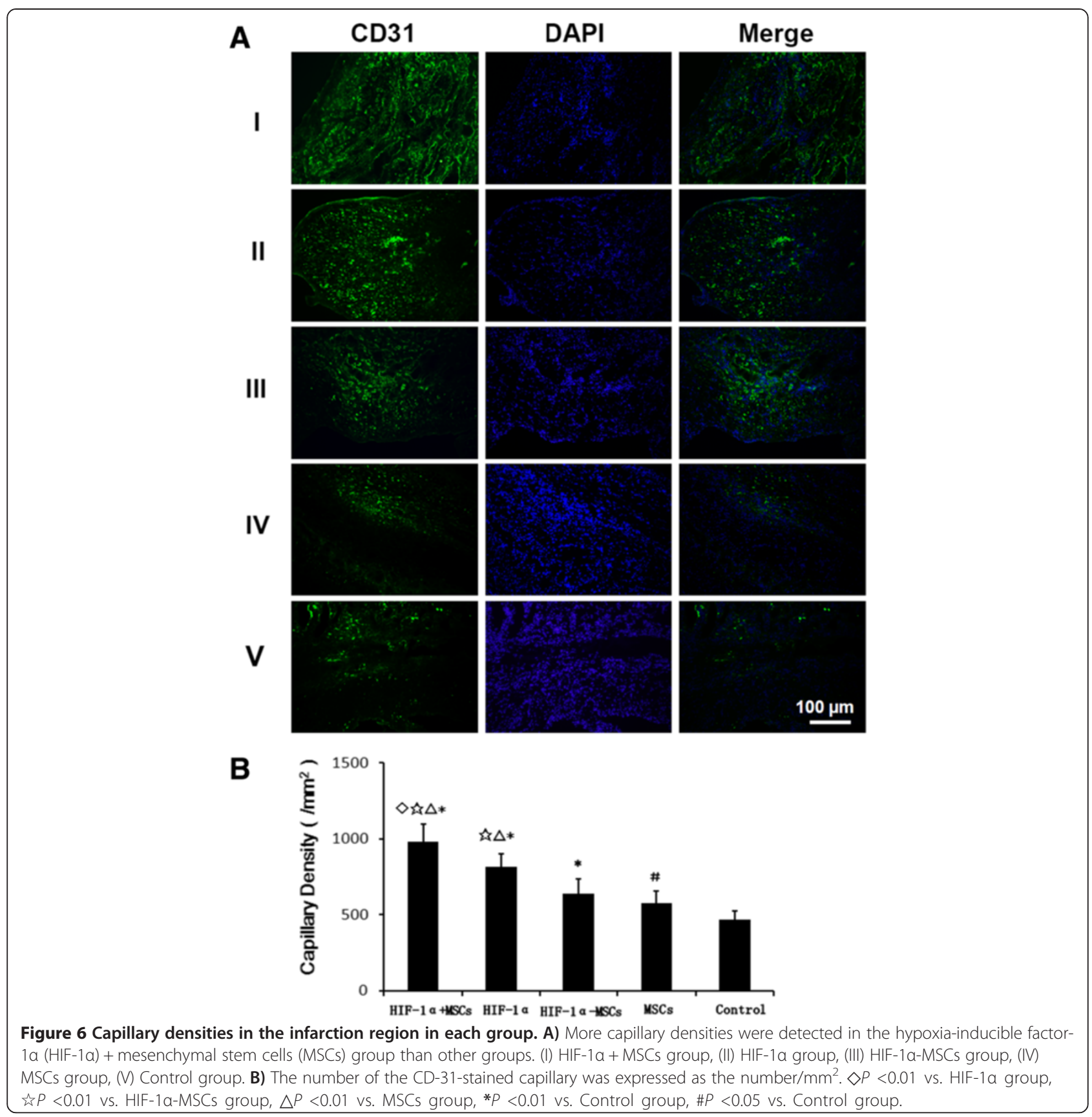

\section{Cardiac performance after myocardial infarction}

In the clinical setting, the prevention of progressive heart failure as a result of myocardial infarction is of great importance. To this end, we assessed the cardiac function after myocardial infarction one week, two weeks and four weeks after myocardial infarction by echocardiography. LVEF and FS evaluated by echocardiograph are shown in Table 2. At one week and two weeks after LAD ligation, markedly decreased LVEF and FS were detected with no significant difference among groups, corresponding to postinfarction myocardial failure. At four weeks after infarction, higher LVEF and FS were observed in the HIF- $1 \alpha+$ MSCs group compared with the HIF- $1 \alpha(P<0.05)$, HIF- $1 \alpha-$ MSCs $(P<0.05)$, MSCs $(P<0.01)$ and Control groups $(P<0.01)$, indicating that the combined HIF-1 $\alpha$ and MSCs intramyocardial injection can significantly improve the cardiac function. No significant differences of LVEF and FS were observed among the HIF- $1 \alpha$, HIF- $1 \alpha-$ MSCs, MSCs and Control groups. 


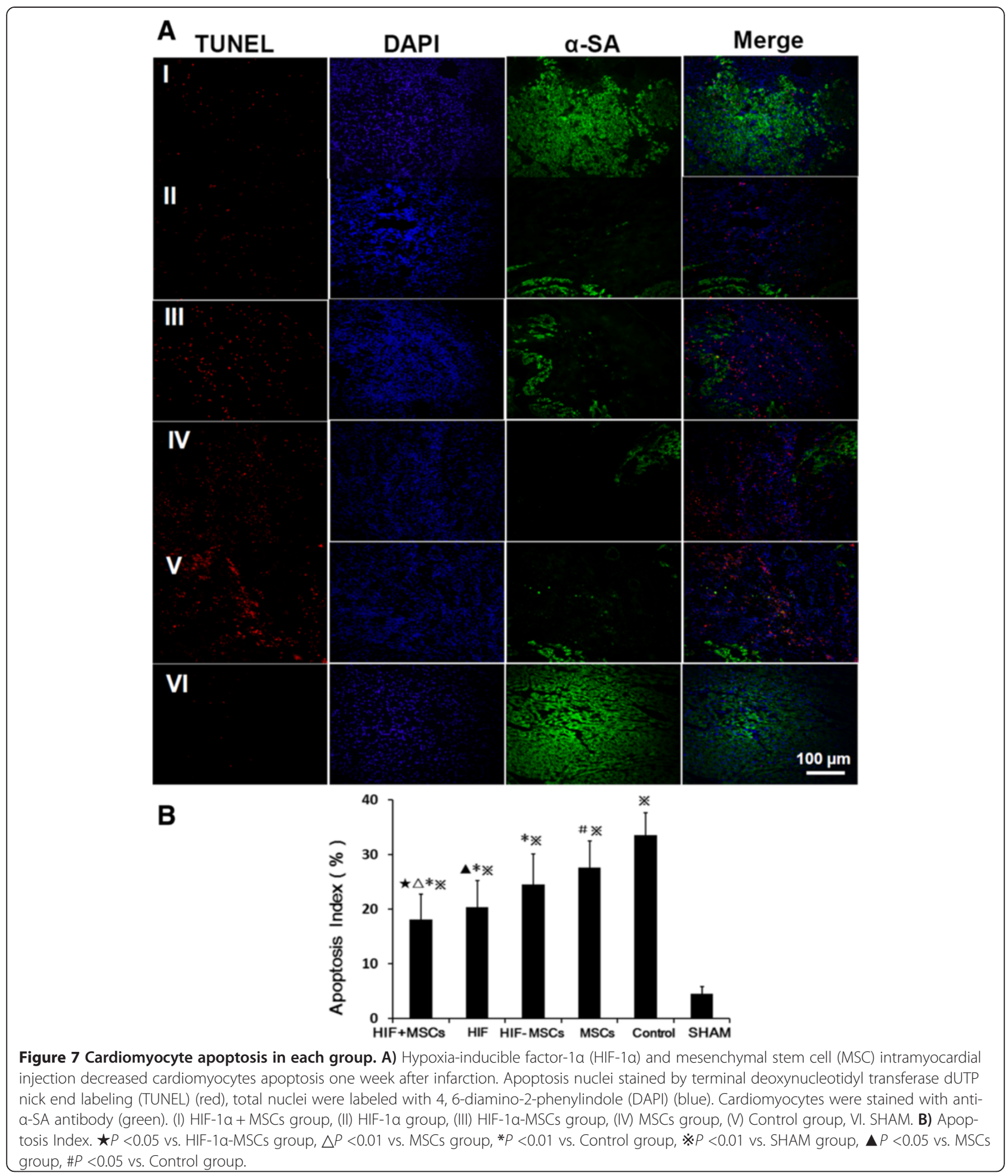

\section{Discussion}

Bone marrow-derived MSCs have become therapeutically important agents because of their multilineage potentials, immuno-modulatory properties and ability to localize specifically to injured sites, to reduce scar tissue formation and to increase neovascularization $[4,40]$. Although many MSC transplantation studies have shown beneficial effects in treating ischemic injury, it is currently limited by the poor engraftment of implanted MSCs due to the harsh microenvironment in the ischemic region 
Table 2 Assessment of LV function (EF and FS) by echocardiography

\begin{tabular}{|c|c|c|c|c|}
\hline Group & Baseline & $1 \mathrm{~W}$ & $2 W$ & $4 W$ \\
\hline \multicolumn{5}{|l|}{ EF (\%) } \\
\hline Control & $91.61 \pm 5.79$ & $32.16 \pm 5.05$ & $30.72 \pm 3.19$ & $25.87 \pm 5.58$ \\
\hline MSCs & $90.51 \pm 6.70$ & $34.97 \pm 5.87$ & $32.23 \pm 8.52$ & $27.26 \pm 6.38$ \\
\hline HIF-1a-MSCs & $91.07 \pm 6.23$ & $35.31 \pm 7.46$ & $33.10 \pm 8.12$ & $29.23 \pm 8.63$ \\
\hline HIF-1a & $92.12 \pm 5.54$ & $35.57 \pm 6.82$ & $32.94 \pm 7.38$ & $30.99 \pm 9.00$ \\
\hline $\mathrm{HIF}-1 \mathrm{a}+\mathrm{MSCS}$ & $91.95 \pm 6.71$ & $37.18 \pm 8.07$ & $38.25 \pm 5.72$ & $40.96 \pm 8.91^{\& \star \Delta *}$ \\
\hline \multicolumn{5}{|l|}{ FS (\%) } \\
\hline Control & $64.71 \pm 2.28$ & $16.48 \pm 2.64$ & $15.17 \pm 1.80$ & $12.60 \pm 2.61$ \\
\hline MSCs & $63.64 \pm 2.21$ & $17.42 \pm 3.20$ & $16.51 \pm 5.38$ & $13.38 \pm 4.52$ \\
\hline HIF-1a-MSCs & $64.07 \pm 2.89$ & $17.57 \pm 4.09$ & $16.64 \pm 4.17$ & $14.35 \pm 4.07$ \\
\hline HIF-1a & $64.92 \pm 2.94$ & $17.86 \pm 3.85$ & $16.53 \pm 3.91$ & $15.62 \pm 4.05$ \\
\hline HIF-1a+MSCs & $64.45 \pm 3.15$ & $18.88 \pm 5.69$ & $19.42 \pm 3.27$ & $21.04 \pm 4.10^{\& \star \Delta *}$ \\
\hline
\end{tabular}

HIF-1a, hypoxia-inducible factor-1a; MSCs, mesenchymal stem cells.

$[4,5]$. Thus, additional strategy is required to enhance the therapeutic efficiency of cell therapy by improving cell homing, survival, engraftment and repair capacity of transplanted cells. One promising strategy may be the combination of cell and gene therapy.

Our results demonstrate that intramyocardial injection of $A d-H I F-1 \alpha$ combined with MSC transplantation was potent to promote angiogenesis, and led to improved cardiac performance after myocardial infarction in the rats. Our study also showed that overexpression of $H I F-1 \alpha$ after $A d-H I F-1 \alpha$ transfection allows for supranormal levels of HIF-1 $\alpha$ mRNA in peri-infarcted myocardium. Consistent with previous studies [29,33], we found that in the SHAM group, without hypoxia, the mRNA level of HIF-1 $\alpha$ was extremely low (Figure 2A1-A3). While in the Control group, which presented the endogenous HIF-1 $\alpha$ expression under hypoxia conditions, the mRNA level of $H I F-1 \alpha$ was significantly increased. The mRNA levels of HIF-1 $\alpha$ in the HIF- $1 \alpha+$ MSCs and HIF- $1 \alpha$ groups were expressed at much higher levels than that of the MSCs and Control groups due to the exogeneous $H I F-1 \alpha$ expression. However, the HIF-1 $\alpha$ mRNA was much lower in the HIF-1 $\alpha$-MSCs group compared to the HIF- $1 \alpha+$ MSCs and HIF- $1 \alpha$ groups. The HIF-1 $\alpha$ expression level in the HIF- $1 \alpha$-MSC group depends on the numbers of engrafted MSCs, which have very low survival rates as evidenced by our data. In contrast, the injected virus could transfect any cell type in the infarcted area, which may explain the observed differences of $H I F-1 \alpha$ expressions among different groups.

We found that the $S D F-1 \alpha$ mRNA expressions were also significantly increased in the HIF-1 $\alpha+$ MSCs and HIF- $1 \alpha$ groups than in that of other groups (Figure 2B1-B3). Previous research found that the SDF- $1 \alpha / C X C R 4$ axis mediated the migration and homing of bone marrow-derived cells and endothelial progenitor cells in vivo [30,41-43]. Consistent with these findings, we found that more MSCs survived and engrafted in the infarcted hearts in the HIF- $1 \alpha+$ MSCs and HIF- $1 \alpha-$ MSCs groups than in the MSCs group. Enhanced angiogenesis, better blood flow and the beneficial effect of several cytokines may contribute to the improvement of the ability of MSCs to survive in hypoxic environments, the migration to the ischemic fibrotic tissue from the border zone, and the angiogenesis in the ischemic area. Since more MSCs survived in the infarcted hearts in the HIF- $1 \alpha+$ MSCs and HIF-1 $\alpha$-MSCs groups, we speculated that the combined therapy may further enhance the angiogenesis at the peri-infarcted and infarct regions compared to the HIF- $1 \alpha$ group, partly due to the MSC-dependent paracrine mechanism.

The mRNA levels of VEGF, regulated directly by $H I F-1 \alpha$, were expressed at much higher level in the HIF- $1 \alpha+$ MSCs and HIF-1 $\alpha$ groups compared to other groups (Figure 2C1-C3). It partly explained why a marked increase in capillary density in the peri-infarcted and infarcted regions was observed in these two groups. Sufficient blood flow as a result of increased blood vessel formation might be instrumental in preventing the loss of cardiomyocytes in these zones over time, preservation of contractility in the border zone adjacent to the infarct, and suppression of post-infarction cardiac failure during left ventricular remodeling [29].

Our findings suggest that myocardial deterioration after infarction in the HIF + MSCs group may be limited not only as a result of stimulation of angiogenesis through a VEGF-related pathway, but also through additional HIF$1 \alpha$-mediated local adaptations to low oxygen tension, and significantly improved microenvironment and increased survival, engraftment and repair ability of MSCs. Furthermore, our research demonstrated that the HIF + MSCs 
group showed better capacity for cardiac repair in terms of the expression of certain important cytokines, such as VEGF, SDF-1 $\alpha$, pro-angiogenesis, anti-apoptosis and restoration of heart function than the HIF-MSCs group. Our report suggests the possibility of using the combination of cell and gene therapy to improve the cardiac repair, without reported side effects, such as fragile and immature vessels and angioma formation $[44,45]$.

Additionally, our study demonstrated that HIF-1 $\alpha+$ MSC treatment was superior to $H I F-1 \alpha$ transfection alone in terms of pro-angiogenesis, anti-apoptosis and the capacity for cardiac function repair. Consistent with previous references [46,47], our study showed that MSCs contribute to the angiogenesis and anti-apoptosis, which may be partly due to the MSC-dependent paracrine mechanism and their potential for trans-differentiation [48-51].

Although we demonstrated that the cell survival rate was higher in the HIF- $1 \alpha+$ MSCs and HIF- $1 \alpha-$ MSCs groups when compared to the MSCs group, the engraftment of cells decreased significantly in all three groups. One hypothesis that may explain the drop-off in engraftment and survival rate is that the exogenous HIF-1 $\alpha$ may have been degraded or metabolized. In our future study, Western blotting will be used to track the amount of HIF-1 $\alpha$ available to cells over time in vivo in order to clarify the role of HIF- $1 \alpha$ in cardiac repair. Furthermore, several studies recently demonstrated encouraging results via the use of biomaterials, such as a dendrimer-type bioreducible polymer or facial amphipathic bile acidconjugated polyethyleneimine, to aid the localization of therapeutic genes to the target cells, thus improving the transfection efficiency and enhancing the cardiac repair [52,53]. Application of such biomaterials in gene therapy holds promise as a potential novel therapy for the treatment of myocardial ischemia and infarction.

So far, the low engraftment of transplanted cells is still the major obstacle to the wide application of stem cell transplantation to treat MI. A series of studies have demonstrated several potential strategies to optimize stem cell engraftment, such as using tissue-engineered collagen-based scaffolds to provide a suitable microenvironment to support cell attachment and proliferation $[54,55]$, or using dynamic three-dimensional culture techniques to enhance MSCs' properties and increase therapeutic potential [56,57]. Recently, our team found that magnetic targeting enhanced the retention of magnetized stem cell in a rat model of myocardial infarction, suggesting that magnetic targeting offers new perspectives for enhancing the cell retention and subsequent functional benefit in heart diseases [58]. And in our future study, we plan to combine physics and biological methods to optimize the engraftment rate.

\section{Conclusions}

We demonstrated that intramyocardial transfection of HIF- $1 \alpha$ and co-transplantation of mesenchymal stem cells enhanced cardiac repair in an experimental model of MI, in correlation with increased ability to induce angiogenesis, reduced apoptosis, and increased survival and engraftment of MSCs, thus having transformative impact on the treatment of patients suffering from severe myocardial ischemia.

\section{Additional file}

Additional file 1: Identification and differentiation assay of MSCs. A. Identification of MSCs. MSCs uniformly expressed CD105 and CD166, but not CD45 or CD34. B. Differentiation assay showed the differentiation potentials of the isolated MSCs into osteoblasts (alizarin red), adipocytes (oiled red) and chondrocytes (alcian blue).

\section{Abbreviations}

Ang: Angiopoietin; CCK-8: Cell Counting Kit-8; DAPI: 4, 6-diamino-2-phenylindole; DiR: 1, 1-dioctadecyl-3,3,3,3-tetramethyl indotricarbocyanine iodide; DMEM: Dulbecco's Modified Eagle Medium; FBS: Fetal bovine serum; FITC: Fluorescein isothiocyanate conjugated; FS: Fractional shortening; GFP: Green fluorescent protein; HIF-1a: Hypoxia-inducible factor-1a; iNOS: Nitric oxide synthase; LAD: Anterior descending coronary artery; LVEF: Left ventricular ejection fraction; MACE: Major adverse cardiac events; MI: Myocardial infarction; MSCs: Mesenchymal stem cells; PBS: Phosphatebuffered saline; PFU: Plate forming unit; SDF-1a: Stromal cell-derived factor-1a; TUNEL: Terminal deoxynucleotidyl transferase dUTP nick end labeling; VEGF: Vascular endothelial growth factor; a-SA: a-sarcomeric actinin.

\section{Competing interests}

The authors have no financial conflicts of interests.

\section{Authors' contributions}

$\mathrm{BQH}$ participated in conception and design, data collection and analysis, and manuscript writing. JYQ contributed to the conception and design, data collection and analysis, and critical revision of the manuscript. JYM and ZYH participated in data collection and analysis, and critical revision of the manuscript. UCG, YLS and XYC contributed to data collection and analysis. AJS participated in the conception and design, obtaining financial support, and manuscript writing. JBG participated in conception and design, data collection and analysis, and manuscript writing. HZC contributed to data collection and analysis, and manuscript writing. All authors read and approved the final manuscript.

\section{Acknowledgments}

The project was funded by the National Natural Science Foundation of China (81370003 and 81000043). The authors thank Mr. Ruiming Yao and Mr. Jianguo Jia for technical assistance.

Received: 10 November 2013 Revised: 18 January 2014 Accepted: 5 February 2014 Published: 7 February 2014

\section{References}

1. Martin-Rendon E, Brunskill SJ, Hyde CJ, Stanworth SJ, Mathur A, Watt SM: Autologous bone marrow stem cells to treat acute myocardial infarction: a systematic review. Eur Heart J 2008, 29:1807-1818.

2. Lipinski MJ, Biondi-Zoccai GG, Abbate A, Khianey R, Sheiban I, Bartunek J, Vanderheyden M, Kim HS, Kang HJ, Strauer BE, Vetrovec GW: Impact of intracoronary cell therapy on left ventricular function in the setting of acute myocardial infarction: a collaborative systematic review and metaanalysis of controlled clinical trials. J Am Coll Cardiol 2007, 50:1761-1767.

3. Abdel-Latif A, Bolli R, Tleyjeh IM, Montori VM, Perin EC, Hornung CA, Zuba-Surma EK, Al-Mallah M, Dawn B: Adult bone marrow-derived cells for 
cardiac repair: a systematic review and meta-analysis. Arch Intern Med 2007, 167:989-997.

4. Das $\mathrm{R}$, Jahr H, van Osch GJ, Farrell E: The role of hypoxia in bone marrowderived mesenchymal stem cells: considerations for regenerative medicine approaches. Tissue Eng Part B Rev 2010, 16:159-168.

5. Shi RZ, Li QP: Improving outcome of transplanted mesenchymal stem cells for ischemic heart disease. Biochem Biophys Res Commun 2008, 376:247-250.

6. Freyman T, Polin G, Osman H, Crary J, Lu M, Cheng L, Palasis M, Wilensky RL: A quantitative, randomized study evaluating three methods of mesenchymal stem cell delivery following myocardial infarction. Eur Heart J 2006, 27:1114-1122.

7. Pons J, Huang Y, Takagawa J, Arakawa-Hoyt J, Ye J, Grossman W, Kan YW, $\mathrm{Su} \mathrm{H}$ : Combining angiogenic gene and stem cell therapies for myocardial infarction. J Gene Med 2009, 11:743-753.

8. Pons J, Huang Y, Arakawa-Hoyt J, Washko D, Takagawa J, Ye J, Grossman W, $\mathrm{Su} \mathrm{H}$ : VEGF improves survival of mesenchymal stem cells in infarcted hearts. Biochem Biophys Res Commun 2008, 376:419-422.

9. Tang J, Wang J, Yang J, Kong X, Zheng F, Guo L, Zhang L, Huang Y. Mesenchymal stem cells over-expressing SDF-1 promote angiogenesis and improve heart function in experimental myocardial infarction in rats. Eur J Cardiothorac Surg 2009, 36:644-650.

10. Zhao T, Zhang D, Millard RW, Ashraf M, Wang Y: Stem cell homing and angiomyogenesis in transplanted hearts are enhanced by combined intramyocardial SDF-1alpha delivery and endogenous cytokine signaling. Am J Physiol Heart Circ Physiol 2009, 296:H976-H986.

11. Shudo $Y$, Miyagawa S, Ohkura H, Fukushima S, Saito A, Shiozaki M, Kawaguchi N, Matsuura N, Shimizu TMP, Okano TPD, Matsuyama A, Sawa $Y$ : Addition of mesenchymal stem cells enhances the therapeutic effects of skeletal myoblast cell-sheet transplantation in a rat ischemic cardiomyopathy model. Tissue Eng Part A 2014, 20:728-739.

12. Chen A, Lee E, Tu R, Santiago K, Grosberg A, Fowlkes C, Khine M: Integrated platform for functional monitoring of biomimetic heart sheets derived from human pluripotent stem cells. Biomaterials 2014, 35:675-683.

13. Shao H, Tan Y, Eton D, Yang Z, Uberti MG, Li S, Schulick A, Yu H: Statin and stromal cell-derived factor-1 additively promote angiogenesis by enhancement of progenitor cells incorporation into new vessels. Stem Cells 2008, 26:1376-1384

14. Zaruba MM, Theiss HD, Vallaster M, Mehl U, Brunner S, David R, Fischer R, Krieg L, Hirsch E, Huber B, Nathan P, Israel L, Imhof A, Herbach N, Assmann G, Wanke R, Mueller-Hoecker J, Steinbeck G, Franz WM: Synergy between CD26/DPP-IV inhibition and G-CSF improves cardiac function after acute myocardial infarction. Cell Stem Cell 2009, 4:313-323.

15. Templin C, Kotlarz D, Faulhaber J, Schnabel S, Grote K, Salguero G, Luchtefeld M, Hiller KH, Jakob P, Naim HY, Schieffer B, Hilfiker-Kleiner D, Landmesser U, Limbourg FP, Drexler H: Ex vivo expanded hematopoietic progenitor cells improve cardiac function after myocardial infarction: role of beta-catenin transduction and cell dose. J Mol Cell Cardiol 2008, 45:394-403.

16. Lee SH, Wolf PL, Escudero R, Deutsch R, Jamieson SW, Thistlethwaite PA: Early expression of angiogenesis factors in acute myocardial ischemia and infarction. N Engl J Med 2000, 342:626-633.

17. Shintani S, Kusano K, li M, Iwakura A, Heyd L, Curry C, Wecker A, Gavin M, Ma H, Kearney M, Silver M, Thorne T, Murohara T, Losordo DW: Synergistic effect of combined intramyocardial CD34+ cells and VEGF2 gene therapy after MI. Nat Clin Pract CardiovasC Med 2006, 3:S123-S128.

18. Forsythe JA, Jiang BH, lyer NV, Agani F, Leung SW, Koos RD, Semenza GL: Activation of vascular endothelial growth factor gene transcription by hypoxia-inducible factor 1. Mol Cell Biol 1996, 16:4604-4613.

19. Semenza GL: Angiogenesis in ischemic and neoplastic disorders. Annu Rev Med 2003, 54:17-28.

20. Jung F, Palmer LA, Zhou N, Johns RA: Hypoxic regulation of inducible nitric oxide synthase via hypoxia inducible factor- 1 in cardiac myocytes. Circ Res 2000, 86:319-325.

21. Ang SO, Chen H, Hirota K, Gordeuk VR, Jelinek J, Guan Y, Liu E, Sergueeva Al, Miasnikova GY, Mole D, Maxwell PH, Stockton DW, Semenza GL, Prchal $\mathrm{JT}$ : Disruption of oxygen homeostasis underlies congenital Chuvash polycythemia. Nat Genet 2002, 32:614-621.

22. Goda N, Ryan HE, Khadivi B, McNulty W, Rickert RC, Johnson RS: Hypoxia-inducible factor 1alpha is essential for cell cycle arrest during hypoxia. Mol Cell Biol 2003, 23:359-369.
23. Wang Y, Feng C, Xue J, Sun A, Li J, Wu J: Adenovirus-mediated hypoxiainducible factor 1alpha double-mutant promotes differentiation of bone marrow stem cells to cardiomyocytes. J Physio/ Sci 2009, 59:413-420.

24. Kubo M, Li TS, Kamota T, Ohshima M, Qin SL, Hamano K: Increased expression of CXCR4 and integrin alphaM in hypoxia-preconditioned cells contributes to improved cell retention and angiogenic potency. J Cell Physiol 2009, 220:508-514.

25. Burns JM, Summers BC, Wang $Y$, Melikian A, Berahovich R, Miao Z, Penfold ME, Sunshine MJ, Littman DR, Kuo CJ, Wei K, McMaster BE, Wright K, Howard MC, Schall TJ: A novel chemokine receptor for SDF1 and I-TAC involved in cell survival, cell adhesion, and tumor development. J Exp Med 2006, 203:2201-2213.

26. Hung SC, Pochampally RR, Hsu SC, Sanchez C, Chen SC, Spees J, Prockop DJ: Short-term exposure of multipotent stromal cells to low oxygen increases their expression of CX3CR1 and CXCR4 and their engraftment in vivo. PLoS One 2007, 2:e416.

27. Tang YL, Zhu W, Cheng M, Chen L, Zhang J, Sun T, Kishore R, Phillips MI, Losordo DW, Qin G: Hypoxic preconditioning enhances the benefit of cardiac progenitor cell therapy for treatment of myocardial infarction by inducing CXCR4 expression. Circ Res 2009, 104:1209-1216.

28. Wenger RH, Gassmann M: Oxygen(es) and the hypoxia-inducible factor-1. Biol Chem 1997, 378:609-616.

29. Kido M, Du L, Sullivan CC, Li X, Deutsch R, Jamieson SW, Thistlethwaite PA: Hypoxia-inducible factor 1-alpha reduces infarction and attenuates progression of cardiac dysfunction after myocardial infarction in the mouse. J Am Coll Cardiol 2005, 46:2116-2124.

30. Ceradini DJ, Kulkarni AR, Callaghan MJ, Tepper OM, Bastidas N, Kleinman ME, Capla JM, Galiano RD, Levine JP, Gurtner GC: Progenitor cell trafficking is regulated by hypoxic gradients through HIF-1 induction of SDF-1. Nat Med 2004, 10:858-864.

31. Farkas E, Timmer NM, Domoki F, Mihaly A, Luiten PG, Bari F: Postischemic administration of diazoxide attenuates long-term microglial activation in the rat brain after permanent carotid artery occlusion. Neurosci Lett 2005, 387:168-172.

32. Cerrada I, Ruiz-Sauri A, Carrero R, Trigueros C, Dorronsoro A, Sanchez-Puelles JM, Diez-Juan A, Montero JA, Sepulveda P: Hypoxia-inducible factor 1 alpha contributes to cardiac healing in mesenchymal stem cellsmediated cardiac repair. Stem Cells Dev 2013, 22:501-511.

33. Shyu KG, Wang MT, Wang BW, Chang CC, Leu JG, Kuan P, Chang H: Intramyocardial injection of naked DNA encoding HIF-1alpha/VP16 hybrid to enhance angiogenesis in an acute myocardial infarction model in the rat. Cardiovasc Res 2002, 54:576-583.

34. Dai Y, Xu M, Wang Y, Pasha Z, Li T, Ashraf M: HIF-1alpha induced-VEGF overexpression in bone marrow stem cells protects cardiomyocytes against ischemia. J Mol Cell Cardiol 2007, 42:1036-1044.

35. Eisenblatter M, Ehrchen J, Varga G, Sunderkotter C, Heindel W, Roth J, Bremer C, Wall A: In vivo optical imaging of cellular inflammatory response in granuloma formation using fluorescence-labeled macrophages. J Nucl Med 2009, 50:1676-1682.

36. Shan L: Near-Infrared Fluorescence 1,1-Dioctadecyl-3,3,3,3Tetramethylindotricarbocyanine lodide (Dir)-Labeled Macrophages for Cell Imaging. Bethesda, MD: Molecular Imaging and Contrast Agent Database (MICAD); 2004.

37. Kalchenko V, Shivtiel S, Malina V, Lapid K, Haramati S, Lapidot T, Brill A, Harmelin A: Use of lipophilic near-infrared dye in whole-body optical imaging of hematopoietic cell homing. J Biomed Opt 2006, 11:050507.

38. Litwin SE, Katz SE, Morgan JP, Douglas PS: Serial echocardiographic assessment of left ventricular geometry and function after large myocardial infarction in the rat. Circulation 1994, 89:345-354.

39. Zhang C, Liu T, Su Y, Luo S, Zhu Y, Tan X, Fan S, Zhang L, Zhou Y, Cheng T, Shi C: A near-infrared fluorescent heptamethine indocyanine dye with preferential tumor accumulation for in vivo imaging. Biomaterials 2010, 31:6612-6617.

40. Arminan A, Gandia C, Garcia-Verdugo JM, Lledo E, Trigueros C, RuizSauri A, Minana MD, Solves P, Paya R, Montero JA, Sepulveda P: Mesenchymal stem cells provide better results than hematopoietic precursors for the treatment of myocardial infarction. J Am Coll Cardiol 2010, 55:2244-2253.

41. Hattori K, Heissig B, Tashiro K, Honjo T, Tateno M, Shieh JH, Hackett NR, Quitoriano MS, Crystal RG, Rafii S, Moore MA: Plasma elevation of stromal 
cell-derived factor-1 induces mobilization of mature and immature hematopoietic progenitor and stem cells. Blood 2001, 97:3354-3360.

42. Neuss S, Becher E, Woltje M, Tietze L, Jahnen-Dechent W: Functional expression of HGF and HGF receptor/c-met in adult human mesenchymal stem cells suggests a role in cell mobilization, tissue repair, and wound healing. Stem Cells 2004, 22:405-414.

43. Wojakowski W, Tendera M, Michalowska A, Majka M, Kucia M, Maslankiewicz K, Wyderka R, Ochala A, Ratajczak MZ: Mobilization of CD34/CXCR4+, CD34/ CD117+, c-met + stem cells, and mononuclear cells expressing early cardiac, muscle, and endothelial markers into peripheral blood in patients with acute myocardial infarction. Circulation 2004, 110:3213-3220.

44. Lopez JJ, Laham RJ, Carrozza JP, Tofukuji M, Sellke FW, Bunting S, Simons M: Hemodynamic effects of intracoronary VEGF delivery: evidence of tachyphylaxis and NO dependence of response. Am J Physiol 1997, 273: H1317-H1323.

45. Carmeliet P: VEGF gene therapy: stimulating angiogenesis or angiomagenesis? Nat Med 2000, 6:1102-1103.

46. Wang Y, Sun A, Xue J, Feng C, Li J, Wu J: Bone marrow derived stromal cells modified by adenovirus-mediated HIF-1alpha double mutant protect cardiac myocytes against $\mathrm{CoCl} 2$-induced apoptosis. Toxicol In Vitro 2009, 23:1069-1075.

47. Gnecchi M, He H, Liang OD, Melo LG, Morello F, Mu H, Noiseux N, Zhang L, Pratt RE, Ingwall JS, Dzau VJ: Paracrine action accounts for marked protection of ischemic heart by Akt-modified mesenchymal stem cells. Nat Med 2005, 11:367-368.

48. Uemura R, Xu M, Ahmad N, Ashraf M: Bone marrow stem cells prevent left ventricular remodeling of ischemic heart through paracrine signaling. Circ Res 2006, 98:1414-1421.

49. Gnecchi M, Zhang Z, Ni A, Dzau VJ: Paracrine mechanisms in adult stem cell signaling and therapy. Circ Res 2008, 103:1204-1219.

50. Landmesser U: Bone marrow cell therapy after myocardial infarction. What should we select? Eur Heart J 2009, 30:1310-1312.

51. Hosoda T: The mircrine mechanism controlling cardiac stem cell fate. Front Genet 2013, 4:204.

52. Won YW, McGinn AN, Lee M, Nam K, Bull DA, Kim SW: Post-translational regulation of a hypoxia-responsive VEGF plasmid for the treatment of myocardial ischemia. Biomaterials 2013, 34:6229-6238.

53. Moon HH, Joo MK, Mok H, Lee M, Hwang KC, Kim SW, Jeong JH, Choi D, Kim SH: MSC-based VEGF gene therapy in rat myocardial infarction model using facial amphipathic bile acid-conjugated polyethyleneimine. Biomaterials 2014, 35:1744-1754.

54. Guan J, Zhu Z, Zhao RC, Xiao Z, Wu C, Han Q, Chen L, Tong W, Zhang J, Gao J, Feng M, Bao X, Dai J, Wang R: Transplantation of human mesenchymal stem cells loaded on collagen scaffolds for the treatment of traumatic brain injury in rats. Biomaterials 2013, 34:5937-5946.

55. Zhao Y, Lin H, Zhang J, Chen B, Sun W, Wang X, Zhao W, Xiao Z, Dai J: Crosslinked three-dimensional demineralized bone matrix for the adipose-derived stromal cell proliferation and differentiation. Tissue Eng Part A 2009, 15:13-21.

56. Frith JE, Thomson B, Genever PG: Dynamic three-dimensional culture methods enhance mesenchymal stem cell properties and increase therapeutic potential. Tissue Eng Part C Methods 2010, 16:735-749.

57. Emmert MY, Wolint $P$, Winklhofer S, Stolzmann P, Cesarovic N, Fleischmann T, Nguyen TD, Frauenfelder T, Boni R, Scherman J, Bettex D, Grunenfelder J, Schwartlander R, Vogel V, Gyongyosi M, Alkadhi H, Falk V, Hoerstrup SP: Transcatheter based electromechanical mapping guided intramyocardial transplantation and in vivo tracking of human stem cell based three dimensional microtissues in the porcine heart. Biomaterials 2013, 34:2428-2441.

58. Huang Z, Shen $Y$, Sun A, Huang G, Zhu H, Huang B, Xu J, Song Y, Pei N, Ma J, Yang X, Zou Y, Qian J, Ge J: Magnetic targeting enhances retrograde cell retention in a rat model of myocardial infarction. Stem Cell Res Ther 2013, 4:149.

\section{doi: $10.1186 /$ scrt410}

Cite this article as: Huang et al:: Myocardial transfection of hypoxiainducible factor- $1 a$ and co-transplantation of mesenchymal stem cells enhance cardiac repair in rats with experimental myocardial infarction. Stem Cell Research \& Therapy 2014 5:22.

\section{Submit your next manuscript to BioMed Central and take full advantage of:}

- Convenient online submission

- Thorough peer review

- No space constraints or color figure charges

- Immediate publication on acceptance

- Inclusion in PubMed, CAS, Scopus and Google Scholar

- Research which is freely available for redistribution 